\title{
The Effect of Service Quality on Customer Satisfaction in the Utility Industry - A Case of Vodafone (Ghana)
}

\author{
Gloria K.Q Agyapong \\ Department of Management Studies, School of Business, University of Cape coast \\ Cape Coast, Ghana \\ E-mail: ritegloria@yahoo.com
}

Received: July 26, 2010 Accepted: November 9, 2010 doi:10.5539/ijbm.v6n5p203

\begin{abstract}
This paper sought to examine the relationship between service quality and customer satisfaction in the utility industry (telecom) in Ghana

The study adapted the SERVQUAL model as the main framework for analyzing service quality. Multiple regression analysis was used to examine the relationships between service quality variables and customer satisfaction. The results showed that all the service quality items were good predictors of customer satisfaction. For managers, this finding has important implications with regard to brand building strategies. Indications of a successful brand building strategy are found when companies provide quality services relative to other companies within the same industry. It is imperative for Vodafone (Ghana) and other telecom firms, therefore, to improve customer services by giving customers what they want and at the right time. Thus, identifying and satisfying customers' needs could improve network services because what is offered can be used to separate the company's services from competitors'.
\end{abstract}

Keywords: Service quality, Customer satisfaction, SERVQUAL model, Utility, Brand, Customer service

\section{Background}

The concept of quality, efficiency, productivity, growth and survival pose a great challenge for the survival and growth of all corporate bodies. These growth and survival demands are further deepened by the need to attract and retain customers, as customers are the main focus of any successful business. Business success depends on a firm's understanding and meeting customers' needs and demands. In Ghana, utility provision has always suffered a setback as utility firms have always been criticised for poor quality of services.

One important utility in an economy is telecommunication. The telecommunication industry's role in an economy cannot be overemphasised. This is because it is the means through which all daily transactions and activities are undertaken. It aids decision making, organizing, influencing, activating, instructing, providing feedback, promoting interpersonal and business relationships as well as exchange of information. All social, economic, political, cultural, trade and commercial activities are undertaken using telecommunication. The nature of a country's telecommunication industry affects its pace of commercial and domestic activities. Due to the poor performance of many of these telecommunication firms, particularly in the developing countries, governments have had to intervene through divestiture and privatisation programmes (Frempong and Henten, 2004).

Indeed, this led to the deregulation of many of the telecom industries in many countries, of which Ghana is no exception (Frempong, 2002). This is because it is believed that state controlled telecom industry may impede innovation, efficiency and could stifle competition as the case was in Ghana prior to the Structural Adjustment Programme (SAP).

Prior to the deregulation of the telecom sector, few firms existed in the country to provide telephone (mobile and fixed line) and Internet services. Meanwhile they charged exorbitant prices but provided restricted and shoddy services. Currently in the telecommunication subsector, five registered firms are operational. They include: Mobile Telecommunication Network (MTN), Millicom Ghana Ltd., Ghana Telecom (now Vodafon Ghana), Kasapa and Western Telesystems (Westel now Zain). The sixth company, Globacom has just acquired its license 
from the National Communications Authority (NCA) - the body charged with the responsibility of registering, supervising and managing the country's telecom sector.

It is perceived that the incoming of those firms has been made possible due to the reforms and adjustment programmes instituted in the country in the 1980s and 1990s. Nevertheless, the presence of these firms has introduced competition, efficiency and effectiveness in the telecom market in the country. Unlike the previous monopolistic, highly regulated telecom market, the presence of the new firms introduced service quality, appropriate and reasonable pricing and social responsibility. In effect, the deregulation policy of the telecom industry has aided in the current level of satisfaction enjoyed by its customers today (Frempong, 2002).

The deregulation, competition and advancement in information communications technology seems to be exerting pressure on managers in this industry to demonstrate customer-focused and continuous service improvement than before, as a way to ensure customer satisfaction and brand supremacy.

Service quality has been found in the literature to be a competitive tool for many companies. This is even much more pronounced in today's highly globalised, industrialised and competitive markets. As has already been mentioned, the growth and survival of companies depend on their customers which telecommunication is no exception.

Several studies have been carried out in the developed countries regarding customer satisfaction and prescriptions have been put forward (Parasuraman et al, 1985; Cronin \& Taylor 1992; Bitner et al, 1990; McAlexander et al, 1994). Also, studies have been carried our regarding the relationship between service quality and customer satisfaction in the developed countries using the SERVQUAL model. However, only few studies have been carried out in this area in the developing counties and the telecom sector. This study, therefore, aims to find out whether there is a relationship between service quality and customer satisfaction in a public sector (telecom) in a developing country context.

It was found that all the service quality variables were significant in explaining customer satisfaction. This finding implies that telecom management should always improve upon their service to continuously satisfy their clients. The next session reviews related literature, followed by data and methodology. The last two sections deal with results and discussion and conclusion and recommendations.

\section{Literature Review}

\subsection{Service Quality}

The definition of quality may vary from person to person and from situation to situation. The definitions of service quality vary only in wording but typically involve determining whether perceived service delivery meets, exceeds or fails to meet customer expectations (Cronin and Taylor, 1992; Oliver, 1993; Zeithaml, Berry and Parasuraman, 1993). Service quality has also been defined by Czepiel (1990) as customer perception of how well a service meets or exceeds their expectations Service quality is commonly noted as a critical prerequisite and determinant of competitiveness for establishing and sustaining satisfying relationships with customers. Previous studying suggests that service quality is an important indicator of customer satisfaction (Spreng and Machoy, 1996). Attention to service quality can make an organisation different from other organisations and gain a lasting competitive advantage (Boshoff and Gray, 2004). In particular, consumers prefer service quality when the price and other cost elements are held constant (Turban, 2002). It has become a distinct and important aspect of the product and service offering (Caruana, 2002). The satisfaction a customer gets from quality of service offered is usually evaluated in terms of technical quality and functional quality (Gronroos 1984). Usually, customers do not have much information about the technical aspects of a service; therefore, functional quality becomes the major factor from which to form perceptions of service quality (Donabedian, 1982). Service quality can be measured in terms of customer perception, customer expectation, customer satisfaction, and customer attitude (Sachdev \& Verma 2004). Ekinci (2003) indicates that the evaluation of service quality leads to customer satisfaction. Rust and Oliver (1994) define satisfaction as the "customer fulfillment response," which is an evaluation as well as an emotion-based response to a service.

Parasuraman, Zeithaml, and Berry $(1988,1990)$ projected a service quality model that identified perceived service quality into five dimensions: tangibility, reliability, responsiveness, assurance, and empathy.

1. Tangibles involve the appearance of physical facilities, including the equipment, personnel, and communication materials.

2. Reliability involves the ability to perform the promised service dependably and accurately.

3. Responsiveness involves the willingness to help customers. 
4. Assurance involves the knowledge and courtesy of employees and their ability to convey trust and confidence. This assurance includes competence, courtesy, credibility and security.

5. Empathy involves the provision of caring, individualised attention to customers. This empathy includes access, communication, and understanding the customer.

Most customers prefer good service to lower prices. Think about all the situations where you are prepared to pay a little extra to get a better or more efficient service. Companies that give these added service benefits are likely to be winners. They have a competitive advantage over rivals. Customers are requiring and demanding better services and the goals of all Telecoms must be to make the customers feel special. This will lead to customer's perceptions exceeding their expectations and greater customer satisfaction. A personal, proactive approach, such as knowing guest history, issues and preferences is vital to impressing customers and increasing repeat business.

\subsection{Customer Satisfaction}

There is lack of consensus among researchers on the subject matter of customer satisfaction. This is because several researchers have looked the concept from different perspectives. Rust and Oliver (1994) suggest that customer satisfaction or dissatisfaction - a "cognitive or affective reaction" - emerges as a response to a single or prolonged set of service encounters. In the words of Giese and Cote (2000), consumer satisfaction comprises three basic components including the type of response (cognitive, affective or conative); the centre of interest or the subject on which the response is focused; and the moment in time at which the evaluation is made. But Anderson and Fornell (1994) are of the view that the literature is not very clear about the distinction between quality and satisfaction. Satisfaction is a "post consumption" experience which compares perceived quality with expected quality, whereas service quality refers to a global evaluation of a firm's service delivery system (Anderson \& Fornell, 1994; Parasuraman et al., 1985).

According to Besterfield (1994), Barsky (1995) and Kanji and Moura (2002), customer satisfaction is a complex construct as it has been approached differently. As expressed by Levesque and McDougall (1996), satisfaction is conceptualized as an overall, customer attitude towards a service provider. Also customer satisfaction has been described as an affective response, focused on product performance compared to some prepurchase standard during or after consumption (Halstead et al., 1994). So Mano and Oliver (1993) establish that satisfaction is an attitude or evaluative judgement varying along the hedonic continuum focused on the product, which is evaluated after consumption. This was reechoed by Fornell (1992), when he identified satisfaction as an overall evaluation based on the total purchase and consumption experience focused on the perceived service performance compared with prepurchase expectations over time.

\subsection{The relationship between Service Quality and Customer Satisfaction}

The SERVQUAL model (Parasuraman, Ziethaml \& Berry, 1988) suggests that the differences between customers' expectations about the performance of a general class of service providers and their assessment of the actual performance of a specific firm in that class results in perceptions of quality. So that the first step in satisfying customers is to determine the level of customer service through service quality assessment. But is there a consensus among researchers, as they argue over whether high degree of service quality always brings about satisfaction. The work of Bitner et al (1990) proposed an alternative method and defined service quality as the customer's overall impression of the relative inferiority/superiority of a firm and its service offerings. Antreas (1997) found that service provider perceptions about customer satisfaction are a function of perceived service quality.

\subsection{Conceptual Framework Developed for the Study}

The framework for the study was adopted and modified from the empirical study by Dehghan, A. (2006) depicted in Figure 1. The figure illustrates the relationship between service quality and customer satisfaction and the characteristics or variables that determines each of them.

\section{$=$ INSERT FIGURE $1=$}

The framework indicates that perceived quality is considered an antecedent of customer satisfaction (Woodside et al., 1989; Reidenbach \& Sandifer-Smallwood, 1990; Cronin \&Taylor, 1992; Fornell, 1992; Anderson \& Sullivan, 1993; Gotlieb et al., 1994; Spreng \& Mackoy, 1996). It indicates that the quality of service measured by the SERVQUAL variables may lead to customer satisfaction. A vast number of specific constructs have been used in conceptual discussions and empirical examinations of customer satisfaction, yet they seem to have at 
least one thing in common (at a very high level of aggregation): they refer to the customer's relationship over time toward one specific object (a vendor, a brand, a service supplier, etc.) (Soderlund, 2005).

In addition, Mittal and Lassar (1998) found that there was a relationship between service quality and customer satisfaction. Elnan and Andersen (1999) proved a positive relationship between service quality and customer satisfaction in the bus industry in Norway. A recent study by Ojo (2010) in the telecommunication industry showed that a positive relationship exists between service quality and customer satisfaction. The same relationship is demonstrated by Cook (2008) and Oyeniyi and Abiodun (2008). Fornell et al (1996) argued that perceived quality, which had been explained as the served market's evaluation of recent consumption experienced, would have a direct and positive impact on overall customer satisfaction. In their development of the American Customer Satisfaction Index (ACSI), they concluded that overall customer satisfaction, especially for ASCI, has three antecedents, which are: perceived service quality, perceived value and customer expectation. The hypothesis for this study thus was:

High level of service quality exerts a strong influence on the overall level of customer satisfaction for Vodafone (Ghana).

\section{Data and Methodology}

The target population of the study comprised 7,621 clients of Vodafone (Ghana) in the Cape Coast Metropolitan area. This was obtained from the database of Ghana Telecom. The company was chosen because as of the time data was collected, the state had a major stake in the company. Also, customers were complaining about their services. This was made known when National Communications Authority (NCA) gave a directive for GT (now Vodafone Ghana) and MTN to halt selling their SIMcards and improve the quality of their services. The branch in Cape Coast was chosen due to time and financial constraints and also to be able to control internal validity. Currently, the company has been privatised with Vodafone holding 70 per cent shares.

To ensure that an adequate number of responses were received, the sample size was determined using Hair et al's (2000) sample size determination formula. Simple random sampling method was used to collect the data. This sampling technique was chosen relative to the others because it is easily understood, the sample results may be projected to the target population and there is no (human) interference in the selection of the sample. However, using this sampling technique, it is often difficult to construct a sampling frame that will permit a simple random sample to be drawn.

The main instrument for data collection was the questionnaire. The questionnaire was developed based on the stated hypothesis and also based on the SERVQUAL model. Both open-ended and closed-ended questions were used. The questions were on a 7-point Likert scale. The scores were coded 7 for strongly agree or strongly satisfied, 6 for moderately agree or moderately satisfied, 5 slightly agree or satisfied, 4 for neutral or indifferent, 3 for somehow disagree or slightly dissatisfied, 2 for disagree or moderately dissatisfied and 1 for strongly disagree or highly dissatisfied.

\subsection{Measurement of Variables}

Service quality was measured by using the variables in SERVQUAL model (Parasuraman, Zeithmal \& Berry, 1988; Ndubisi, Chan, \& Chukwunonso, 2004). In using the SERVQUAL instrument, 21 statements measured the service quality across these elements, using a seven point Likert scale. The factors in the model were measured as follows:

- Tangibles - appearance of physical facilities, equipment, personnel.

- Reliability - ability to perform the promised service dependably and accurately.

- Responsiveness - willingness to help customers and provide prompt service.

- Competence - possession of required skill and knowledge to perform service.

- Courtesy - politeness, respect, consideration and friendliness of contact personnel.

- Feel secure - freedom from danger, risk, or doubt.

- Communication - listens to its customers and acknowledges their comments. Keeps customers informed. In a language which they can understand.

- Understanding the customer - making the effort to know customers and their needs.

The performance ratings of cellular phones reported in consumer reports (1998) was used by Lee et al (2001) as a basis for measuring consumer satisfaction where the opinions of consumers regarding pricing plan, core services (coverage of the calling area and the clarity of sound) and value added services (precision of billing 
services and easy access to provider). This was modified and customer satisfaction is measured by using customer complaint rate, negative affect/emotions, reluctant to switch, customer service, first choice and search motivation.

Five hundred and twenty (520) questionnaires were administered at the company's main office and retail outlets where the Vodafone's products are sold in the Cape Coast Metropolitan Area. On the whole, out of the 520 respondents visited, about 460 provided completed questionnaires; the remaining questionnaires were given back uncompleted. This resulted in 88 per cent retrieval.

To achieve the objective of this study, that is to examine the impact of service quality on customer satisfaction in utility industries in Ghana, multiple regression analysis was carried out. The fitted regression model is:

$$
\begin{aligned}
& Y=\alpha+\sum_{i}^{n} \beta_{i} X_{i}+\varepsilon_{t} \\
& Y_{i}=\text { Customer satisfaction }
\end{aligned}
$$

Where $X_{i}$ is a vector of service quality variables (Competence, Tangibility, Reliability, Communication, Security, Courtesy)

$\alpha$ is the intercept and $\beta_{i}$ are the respective coefficients measuring the sensitivity of each service quality variable to customer satisfaction.

A major strength of the multiple regressions is that the questions raised in the context of bivariate regression can be answered by considering additional independent variables. (Malhotra, 2007).

\section{Results and Discussions}

The regression model showed that $63 \%\left(\mathrm{R}^{2}=0.633\right)$ of the observed variability in total customer satisfaction is explained by the total service quality variables. Further, the regression model shows how the individual service quality variables affect customer satisfaction. The result indicates that all the service quality items; competence, service tangibility, staff courtesy, security, communication and reliability are good predictors of customer satisfaction.

$$
=\text { INSERT TABLE } 1=
$$

The significance of the F-Statistics $(F$-value $=130.0)$ indicates that there is a relationship between the dependent variable (CS) and the six independent variables (service quality factors). In other words, since the observed significance level is less than 0.005 , it indicates that the service quality items are the main factors that affect customer satisfaction of Vodafone (Ghana).

Furthermore, the regression equation shows that if no initiatives are taken to increase the level of the identified variables (i.e. competence, service tangibility, staff courtesy, security, communication and reliability) the level of customer satisfaction will decrease. In addition, Vodafone (Ghana) must put more effort into improving the competence of staff and also making their services more tangible to customers' needs since the two are the most significant factors influencing customer satisfaction.

\section{Conclusions and Recommendations}

These findings imply that recruiting competent staff may be a critical aspect for customers in judging the quality of telecommunication services.

There is a positive relationship between service quality and customer satisfaction. Obtaining customer satisfaction depends to a large extent on ensuring that the firm maintains high service quality standards. Putting in place quality mechanisms has significant effect on the level of customer satisfaction. Hence the hypothesis was substantiated. Among the service quality variables that significantly affected customer satisfaction include competence, courtesy, tangibility, reliability, responsiveness and communication. For managers, this finding has important implications with regard to brand building strategies. The study documented that service quality is the dominant route to customer satisfaction. Indications of a successful brand building strategy are found when companies provide quality services relative to other companies within the same industry.

It is imperative for Vodafone (Ghana) and other telecom firms in Ghana, therefore, to improve customer services by giving customers what they want, when they want it. Thus, identifying and satisfying customers' needs could improve network services because what is offered can be used to separate the company's own services from competitors'. 
Telecom management needs to emphasize service quality. Due to the fact that telecom firms do not provide tangible products, their service quality is usually assessed by measures of the service-provider's relationship with customers. Thus, telecom service management should pay attention to staff skill possession, knowledge, attention to customers and their needs, offering of fast and efficient services and general attitude to customer services. Other issues for improving upon customer satisfaction in the telecom services include confidentiality in transactions, trustworthiness, extension of working hours, and provision of insurance for customers. Policymakers for the company should therefore see to customer satisfaction based on these measures.

Invariably, there is need for the management of telecom firms to intermittently train their workers on relationship marketing skills. Such training would build a customer-oriented climate in which contact staff can deliver service efficiently and effectively, acknowledging that acquiring and retaining customers is the very essence of marketing. Consequently, customer relations behaviours can serve as the criteria for telecom staff performance evaluations and promotions.

The key to customer creation and retention appears to be the fostering of a favourable relative attitude among clients. Thus it is not merely enough to satisfy a customer, the customer's attitude towards a specific network should be more favourable as compared to competing networks; and a favourable relative attitude can be created by satisfying the customers through improved service quality.

It is also suggested to managers that to lessen the degree of mixed feelings following a poor service recovery, service organizations might consider sending customized communication messages to disgruntled customers. Reminding the customer about the positive aspects of the service operation might be enough to bolster positive feelings, and thereby reduce attitude ambivalence that can lead to customer satisfaction.

\section{References}

Anderson, E \& Sullivan, M.W. (1993). The antecedents and consequences of customer satisfaction for firms. Marketing Science, 12 (2), 125-43

Anderson, E.W., \& Fornell, C. (1994). Customer satisfaction, market share and profitability: Findings from Sweden. Journal of Marketing, 58(3), 53.

Antreas, D.A. (1997). Another look into the agenda of customer satisfaction. International Journal of Bank Marketing.

Barsky, J. (1995). World-class customer satisfaction. Burr Ridge, IL: Irwin Professional.

Besterfie ld, D.H. (1994). Quality Control. Englewood Cliffs, NJ: Prentice-Hall.

Bitner, M., Booms, B., \& Tetreault, M. (1990). The service encounter: diagnosing favourable and unfavourable incidents. Journal of Marketing, 54(1), 71-84.

Caruana, A. (2002). Service loyalty: The effects of service quality and the mediating role of customer satisfaction. European Journal of Marketing, 36(7/8), 811-828.

Consumer Reports. (1998). Buying Guide Issue. September, Consumers Union of United States, New York.

Cronin, J. J. Jr \& Taylor, S. A. (1992). Measuring service quality: A re-examination and extension. Journal of Marketing, 56, 405-20.

CzepieI, J. A. (1990). Service encounters and service relationships: Implications for research. Journal of Business Research, 20: 13-21.

Donabedian, A. (1982). Explorations in quality assessment and monitoring: The definition of quality and approaches to its assessment. Ann Arbor, Michigan: Health Administration Press.

Ekinci, Y. (2003). An investigation of the determinants of customer satisfaction. Tourism Analysis, 8(2), 193-196.

Elnan, H., \& Anderson, O. (1999). Measuring and monitoring service quality in the bus industry. Proceeding of the $3^{\text {rd }}$ Asian Academy of Management Conference.

Fornell, C. (1992). A national customer satisfaction barometer: The Swedish experience. Journal of Marketing, $56,6-21$

Fornell, C., Johnson, M.D., Anderson, E.W., Cha, J., \& Bryang, B.E. (1996). The American customer satisfaction index: Nature, purpose, and finding. Journal of Marketing, 60, 7-18

Frempong, G. (2002). Telecommunication Reforms - Ghana's Experience. Discussion Paper, Technical University of Denmark. 
Frempong, G. K \& Henten, A. (2004). Telecom Developments and Investments in Ghana WDR Dialogue Theme, Discussion Paper, Technical University of Denmark.

Giese, J. L., \& Cote, J. A. (2000). Defining consumer satisfaction. Academy of Marketing Science Review (on line).

Gotlied, J.B., Dhurv, G., \& Brown S.W. (1994). Consumer satisfaction and perceived quality: Complementary or divergent constructs? Journal of Applied Psychology, 79(6), 875-885.

Gray, B. (2004). The relationships between service quality, customer satisfaction and buying intentions in the private hospital industry. South African Journal of Business Management, 35(4), $27-37$.

Gronroos C.A. (1984). Service Quality model and its marketing implications. European Journal of Marketing, 18 (4), 36-44.

Hair, J.F. Jnr., Bush, R.P \& Ortinau D.J. (2002). Marketing research: A practical approach for the new millennium. New York: Irwin McGraw-Hill.

Halstead, D., Hartman, D., \& Schmidt, S.L. (1994). Multisource effects on the satisfaction formation process. Journal of the Academy of Marketing Science, 22, 114-29.

Kanji, G., \& Moura, P. (2002). Kanji's business scorecard. Total Quality Management, 13(1), 13-27.

Lee, J., Lee, J., \& Feick, L. (2001). The impact of switching costs on the customer satisfaction-loyalty link: Mobile phone service in France. Journal of Services Marketing, 15(1), 35-48.

Levesque, T., \& McDougall, G. (1996). Determinants of customer satisfaction in retail banking. International Journal of Bank Marketing, 14(7), 12-20.

Mano, H., \& Oliver, R.L. (1993). Assessing the dimensionality and structure of the consumption experience: evaluation, feeling, and satisfaction. Journal of Consumer Research, 20, 451-66.

McAlexander, J.H., Kaldenberg, D.O., \& Koenig, H.F. (1994). Service quality measurement. Journal of Health care Marketing, 14(3), 34-40.

Mittal, B., \& Lassar, W.M. (1998). Why do customers switch? The dynamics of satisfaction versus loyalty. Journal of Services Marketing, 12(3), 177-94.

Ndubisi, N.O., Chan, K.W., \& Chukwunonso, N.C. (2004). Evaluating relationship marketing strategies and customer loyalty. International Logistics Congress Proceeding, 11, Izmir.

Ojo. (2010). The relationship between service quality and customer satisfaction in the telecommunication industry: Evidence from Nigeria. Broad Research in Accounting, Negotiation, and Distribution, 1(1), 88.

Oliver, R. L. (1993). Cognitive, affective, and attribute bases of the satisfaction response. Journal of Consumer Research, 20, 418-430.

Oyeniyi, O., \& Abiodun A. J. (2008). Customer service in the retention of mobile phone users in Nigeria. African Journal of Business Management, 2 (2), 026-031. [Online] Available: http://www.academicjournals.org/AJBM

Parasuraman, A., Ziethaml, V.A., \& Berry, L.L. (1985). A conceptual model of service quality and its implications for further research. Journal of Marketing. 49, 41-50.

Parasuraman, A., Ziethaml, V.A., \& Berry, L.L. (1988). SERVQUAL: A multiple-item scale for measuring consumer perceptions of service quality. Journal of Retailing. 64(1), 12-40.

Reidenbach, R.E. \& Sandifer-Smallwood, B. (1990). Exploring perceptions of hospital operations by a modified SERVQUAL approach. Journal of Health Care Marketing, 10, 47-55.

Rust, R.T., and Oliver, R.L. (1994). Service quality: insights and managerial implications from the frontier. In Rust, R.T. \& Oliver, R.L. (Eds), Service quality: New directions in theory and practice, 241-68.

Sachdev, S. B., and Verma, H. V. (2004). Relative importance of service quality. Journal of Services Research, 4(1), 93-116.

Söderlund, M. (1998). Customer satisfaction and its consequences on customer behaviour revisited. International Journal of Service Industries Management, 9(2), 169-88.

Spreng, R.A., \& Mackoy, R.D. (1996). An empirical examination of a model of perceived service quality and satisfaction. Journal of Retailing, 72(2), 201-14. 
Spreng, R.A., \& Olshavsky, R.W. (1992). A desires-as-standard model of consumer satisfaction: implications for measuring satisfaction. Journal of Consumer Satisfaction, Dissatisfaction and Complaining Behaviour, 5, 45-54.

Turban, E. (2002). Electronic commerce: A managerial perspective. New York: Prentice Hall.

Woodside, A.G., Frey, L.L., \& Daly, R.T. (1989). Linking service quality, customer satisfaction and behavioral intention. Journal of Health Care Marketing, 19, 5-17.

Zeithaml, V. A., Berry, L. L., and Parasuraman, A. (1993). Delivering quality service: Balancing customer perceptions and expectations. New York: New York Free Press.

Table 1. Relationship between Service Quality and Customer Satisfaction

\begin{tabular}{lcc}
\hline VARIABLES & CO-EFFICIENTS & t-VALUES \\
\hline Constant & -.956 & $-3.498^{*}$ \\
Competence & .451 & $8.645^{*}$ \\
Tangibility & .580 & $7.787^{*}$ \\
Reliability & -.276 & $-6.154^{*}$ \\
Communication & .207 & $5.884^{*}$ \\
Security & .149 & $-2.783^{*}$ \\
Courtesy & .188 & $4.151^{*}$ \\
\hline
\end{tabular}

F-Statistics $=(130.00,000)$

R-Square $=.633$

Adj. R-Square $=.628$

Dependent Variable: Customer Satisfaction

${ }^{*}$ Regression is significant at .01 level

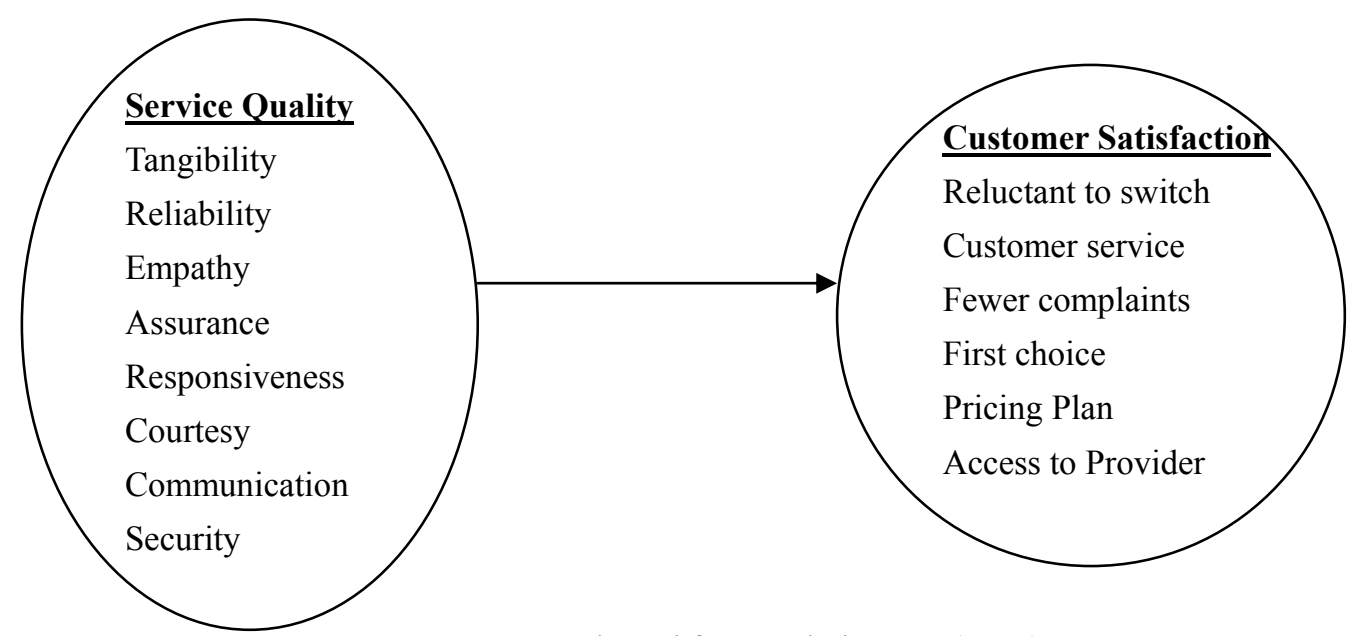

Source: Adopted from Dehghan, A. (2006)

Figure 1. Relationship between Service Quality and Customer Satisfaction 